\title{
Critical Success Factors of Public Private Partnership for Affordable Housing in Nigeria
}

\author{
Yahaya Ahmed, Ibrahim Atan Bin Sipan
}

\begin{abstract}
Public private partnership was introduce by the Nigerian Government as an option to end the current crisis of housing shortage and affordable housing in the country. The aim of this paper is to identify the critical success factors of PPP for provision of affordable housing in Abuja. Based on the current studies PPP has not made any significant contribution to housing for low-income earners; rather it is suddenly change towards providing housing for high- and middle-income earners. The paper relies on interview with PPP expert to build up questionnaire survey on success factors of PPP for affordable housing in Nigeria. In total, 254 responses were obtain and analyzed using smart PLS to determine the success factors of PPP for affordable housing in Abuja. The results reveals that there are Six key component success factors of PPP for affordable housing provision in Abuja, this include; Strong Government support, access to alternative fund, favorable investment environment, available of competent personnel, transparency procurement process, and open communication among others. It therefore suggests that government should strongly provide a policies to support the success of PPP for affordable housing provision in Abuja, and also provide a means of subsidy to promote PPP toward provision of affordable housing. Therefore, it's recommended that a good framework on affordable housing using PPP should put in place for a successful affordable housing provision.
\end{abstract}

Index Terms: Critical Success Factors, Public Private Partnership, Affordable housing, Abuja, Nigeria.

\section{INTRODUCTION}

Rural urban migration and the massive increase in population are the serious challenges affecting the capacity of most government in providing adequate and affordable housing in the developing countries. The United nation (2014), has projected that by the year 2050 urban population will increase to about 2.5 billion of people with about $90 \%$ increase in developing countries like Sub saharah Africa and Asia because there are poorest region in the world. Consequently, the challenges of housing provision in Nigeria today have become more complicated particularly among the low income group who have the largest urban population (Federal Republic of Nigeria, 1991). After several effort by the Nigerian government since after independence in 1960 to solved the challenges of housing provision, the government fail to meet up with the

Revised Manuscript Received on September 22, 2019.

Yahaya Ahmed, Faculty of Built Environment and surveying, Department of Property Development, Universiti Teknologi Malaysia, 81310 Skudai, Johor, Malaysia , yahmednas1@gmail.com

Ibrahim Atan Bin Sipan, Faculty of Built Environment and surveying, Department of Property Development, Universiti Teknologi Malaysia, 81310 Skudai, Johor, Malaysia. challenges to provide adequate and affordable housing in the country (Awotona 1990; Oruwari 2006)

Considering the fact that housing situation is worsening in Nigeria, several elements are consider as the main factors of an increase in housing declines in sub-Saharan Africa cities, this includes strict land use and use policies and discrimination; lack of coordination of public housing agencies; and high cost of construction materials and legislation (Ademiluyi and Raji, 2008). Rondinelli (1990) found that the failure of Nigeria and some sub Saharah cities to cope with the housing need in their perspectives area. As stated by African Ministerial Conference on Housing and Urban Development (AMCHUD, 2005, p. 5), African region is unable to meet up with the housing crisis for their inability to transform their organizations and values to the dynamic positive situation.

This suggests that both the public and private sectors in the African region have adopted incorrect organization framework and a non-functional housing delivery system in the past, and therefore, housing challenges in the continent have increased rapidly. Among the international development agencies that are involved in housing is, the United Nations Global Strategic Organization Shelter that advised that African countries including Nigeria to withdraw from housing as it is unable to meet the growing housing demand due to wrong approach adopted to address quantitative and qualitative shortages. The present housing situation in Nigeria and other developing nations brought in picture that the provision of housing and other infrastructural facility cannot be provided by the government along to the citizens, rather partnership with private developers as advice by the united nation as alternative solution to housing crisis.

However, on the UN recommended to African countries to put more responsibility for housing provision in the private sector through Public-Private-Partnerships (PPPs) (Ibem and Aduwo, 2012). Miraftab (2004) found that Public-Private Partnerships (PPPs) awere recognized as the arrangement of alternative institutions and approaches to civil service in cities in developing countries. In housing provision, PPP is promoted on the assumption that it will increase the interest of housing sector capabilities, and the expansion of housing capabilities and facilities (Shelter Afrique, 2008). Based on this recommendation the Nigerian government in 2004 adopted the PPP in the proposal to

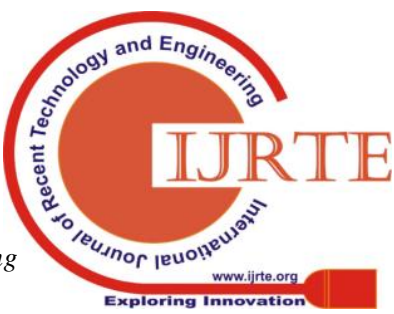




\section{Critical Success Factors of Public Private Partnership for Affordable Housing in Nigeria}

increase housing supply in the country cities of Abuja and Lagos (Owei, 2007). The Government believes that PPP will improve efficiency in

public administration and delivery of services through the editing of private and professional sector funds (Lagos State Government, 2008).

However, despite PPP's appeal, the success and failure of its applications in housing delivery has not been systematically reviewed (Jamali 2004b; Van Ham \& Koppenjan 2010; Alinaitwe\&Ayesiga 2013). The use of PPP in housing delivery is less than the infrastructure provision (Ong 2003; Abdul-Aziz \&Kassim 2011; Trivedi \&Ajit 2014). PPP programs, since the 1990s, have become the education, health, and transport infrastructure sectors ( $\mathrm{Li}$ \&Akintoye 2008). For this reason, PPPs in housing provision are poorly studied worldwide (Ong et al., 2002; Sengupta 2005; Abdul-Aziz 2012). The PPP in housing transfers has largely escaped academic research (Payne 2000) and has yet to have different spaces in both theory and application (Sengupta, 2005). Thus, the explanation factor for the successful delivery of PPP housing is still poorly understood especially in the context of developing countries such as Nigeria. The PPP initiative is in the early stages of most developing countries in the world, and its knowledge base has not yet been explored (Awodele et al. 2008). As supported by UN-HABITAT (2011), PPP housing programs in developing countries are rare, with little empirical data showing the trends of success. Moreover, PPP has become the major solution to housing challenges as stated in the literature that most countries in the world are now using PPP to tackle their housing problems (Ong and Lenard, 2002; Freut, 2005; UN-HABITAT, 2006b). Therefore, this studies tend to look at the success factors use by some countries like, Malaysia UK, India, Canada and Australia among others that successfully achieved in housing provision using success factor of PPP and apply to Nigeria.

\section{LITERATURE REVIEW}

Public housing provision in Nigeria as review by the literature, identifies three fundamental approached as used in the pass: government-assisted self-help housing, direct construction of housing units and slum clearance and upgrading initial to the inception of colonial rule in Nigeria. As observed by Mayaki (2003), government has not made any attempt to inhance the housing conditions. However, between 1973 and 1995 about 36 cases of slum clearance and upgrading were report in Nigeria (Agbola and Jinadu., 1997). The iisue of slum clearance did not meet the aim of providing affordable housing in Nigeria as observed by UN-HABITAT (2006a), due to the insufficiency of funds to make available housing and services to displace people and unavailable of suitable land.

In 1970s government initiate self-help housing scheme through an arrangement with federal and state government and the World Bank. This arrangement is to help the low and middle income people to build their houses through the self-help efforts. Government had make available of about 24,397 plots through the institutional framework and counterpart funding. Due to the management limitation this programme was not extend to other state. The government made an attempt in 1986 to recue this programme through the national site and service scheme in Kano, Lagos, ondo, Kwara, Imo, Rivers state inconjuction with Abuja, the Federal capital of Nigeria (UN-HABITAT, 2006a). Land was provide and surveyed it into plots by the Federal Housing authority (FHA), the supervising agency. Also basic infrastructure (e.g. electricity, water and roads) was provide by the Federal Housing Authority (FHA), in some instances the government build core housing unit on the plot. Government spent almost N58 million (US 21.25 million) from 1986 - 1991 to provide 20,000 appropriate plots in 20 state of the country. However, the procedure of allocation this plot and high cost of the service plot give opportunity in favoure of the government official and their partners, this assisted self-help scheme did not favor the low income group (Bana 1991; Mba 1992).

Consequently, the social provision of PPP depend on the concept that will take to reduce the government expenses (Brown et al., 2006) and the service provide at affordable price (Klijn \& Koppenjan, 2000). with the reference above that stated were PPP used as social provision, its identify that government worked jointly with private organization providing adequate serviced to cut down the government spending.

However, no evidence recommending that the services provided were more affordable compared with other options, as proposing that PPP provision of affordable housing need more appraisal against this background, one can conclude that, PPP involve joint decision making, engagement of resources, sharing of duties, risk and benefit, division of labour and interdependence among stakeholders.

In housing provision, a study of PPP has been in different theoretical view (UN-HABITAT, 2006b). In view of this study, the significant of PPP is on rate of available housing provided together with affordable housing and accessibility in the PPP approach. PPP is proposing to boost the productivity and effectiveness of public housing sector through multi sectorial engagement within the framework of market strategies as it faithful in other social services provision (Mukhija, 2004; UN-HABITAT, 2006b). Apart from the volume of housing provided, one more issue concern of PPP beside the volume of housing provided, is how to improve on affordable housing.

Australian Housing and Research Institute (AHURI, 2004), stated that housing affordability refers to the scope of households to meet housing costs while maintaining the ability to meet other basic costs of living.

Therefore, it is generally accepted that affordable

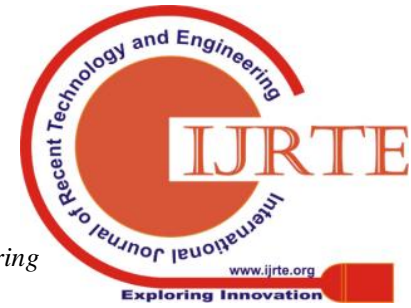


housing is that which costs not more than between 25 per cent and 30 per cent of the householder income (Aribigbola, 2008). Jiminez and Kieve (1993) and Oruwari (1993) noted that housing affordability is a observable idea that changes with time. This involve that it is an individual ability to see on how much households are set to pay for housing within the limit of their incomes. Evidence indicated that PPP had develop an affordable housing for the low income group in country like Malaysia, Australia Brazil and other developing countries (Ong\&Lenard, 2002; Fruet, 2005; UN-HABITAT, 2006b). Affordable housing in the study observed as independent view on the ability to householder to pay for PPP providing affordable housing in Abuja.

Specifically, Nigeria and other developing countries brought about the fact that the government alone cannot solve the responsibility of providing adequate housing to the citizen's couple with current situation. As confirm by (UNCHS 1992; World Bank 1993; Payne 1999; Ogu 2001; Mukhija 2004) that both the public and private sector not independently solve the problem of housing in the country.

Consequently, partnership between stakeholders in the housing sector have become certain (Obeng-Odoom 2009). As noted by African Ministerial Conference in Housing and Urban Development (2005), that most African countries should adopt PPP as a new perspectives to housing provision. As observed by Ikekpeazu (2004:30) and Owei (2007), Public-Private Partnership (PPP) has being searched in Nigeria as a solution to the current housing problem. Literature review discover the different PPP outcomes that are affected by the structure and attribute of the partnership. The study of Fruet (2005) and UN-HABITAT (2006b), indicate in spite of the fact that the result of PPP in housing provision different from one country to another, the responsibility of government organization, commercial private and non-beneficial private sector in the procedure were the key component with sufficient impact on the result of PPP for housing provision

Consequently, the evaluation of PPP in housing provision in Abuja concentrate mostly on the structure and composition of the PPPs as well as the scope to which PPP housing schemes have solve the problems of inadequate housing supply, affordable housing and accessibility.

\section{A. Public Private Partnership Housing Provision In Nigeria.}

Public private partnership application for housing provision is not new in Nigeria, it was established at about seventeen years ago when the country officially adopted the method in public housing provision. Nigeria launched the New National Housing and Urban Development Policy (NNHUP) in 2002 under the leadership of olusegun Obasanjo and recognize the PPP as alternative to housing provision. The emphasis shift from the government provider approach is informed by the failure of the past efforts of the successive governments to address the growing urban housing crisis in the country. Therefore, the government sees the need to promote access to good, safe and clean housing accommodation at affordable price through a private sector-led initiative. It has been explained in this policy document that the adoption of the PPP approach to public housing is to ensure that the private sector plays a more active role in solving the problem of serious housing costs in the country. This is why most housing projects in the country are currently being implemented through the PPP approach. There are three main PPP drivers in Nigeria.

Nigeria has three key control of PPP for housing provision. High urbanization rate is the first driver, which contributes to the growing demand for housing beyond the public and private sectors that can meet freely. Second driver, the constrain of budgetary allocation and other competitive demands, the need to ease the government's burden of financing the provision of public housing (Ibem and Aduwo, 2012). The third driver is the identification that the private sector has great potential in meeting the needs of housing because of its large human and financial resources. UN-HABITATA (2006a) stated that more that 80 percent of housing provision in Nigeria is provided by private sectors. On the basis of this, it is general believed that solution to low income housing by PPP is to create a surroundings that will permit privates and non-commercial private sectors organizations to fully profit to handle the actual production of UN-HABITAT housing units, 2006b).

This is in line with the approaches that enable housing and infrastructure to provide, which have obtained world acceptance and record important results in many developing countries such as Malaysia, Australia, India, Brazil and the Philippines among others to mention these. With the application of PPP in Nigeria in the recent time. Some of the PPP attribute in the country experience can be mention. The first attribute is that in spite the fact that the NNHUP has provide a legal framework for adoption of public private partnership in housing in Nigeria, current practice disclose that other laws have been designed to regulate the activities of PPP's housing provision and infrastructure project operators in the country. Among them are the Infrastructure Concession Regulatory Commission (ICRC). Act 2005; The National Policy on Public-Private Partnership in Nigeria launched in 2009, the Public Procurement Act 2007; PPP Guidelines issued by the ICRC governing PPP ICRC, 2012), the Land Use Act 1978 as amended in 2004 and various "PPP Manuals and Guidelines. The deduction of this law is formulated to ensure PPP's efforts in this country are implemented in the framework of the procedures set forth and adhere to global best practices in promoting equity, transparency and value for money. In fact, they are part of the government's efforts to ensure there are promising policies and regulations for the implementation of PPP projects in Nigeria (Federal Republic of Nigeria (FRN), 2009).

In addition, Ibem (2010) has revealed that PPP housing projects are usually implemented based on the 


\section{Critical Success Factors of Public Private Partnership for Affordable Housing in Nigeria}

Memorandum of Understanding (MOU) signed by all partners in the PPP housing project. The MoU is considered as an operational document and law that establishes PPP and helps to guide their operations on each project. Among other things, MOU reflects the nature and structure of housing projects, the role of partners and their contribution and equity benefits (Ibem, 2011a). There is also a development lease agreement (DLA), this is part of an operational document signed by a partner to PPP housing project in Nigeria. DLA represents the commitment of all parties to ensure that PPP housing projects are successfully executed according to the specifications outlined in the MOU.

There is need to state the important that that apart from the generic laws in the PPP, MOU and DLA industries are the most common instruments used by PPP use operators in the implementation of PPP housing projects in Nigeria. It is important to note here. As a result, many operators and observers see these documents as a replacement for the PPP housing base in Nigeria. Unfortunately, this should not be repeatedly noted that these operating documents are full of difficulties in terms of enforcement by partners in PPP housing projects.

The second major feature that can illustrate Nigeria's PPP experience in housing is the institutional framework for the implementation of PPP housing projects. The NNHUP has provide a legal framework for establishing an organization that can represent an established private sector in PPP housing projects in recognition of the importance of a strong institutional framework in the effective delivery of housing. Nigeria Property Developers Association (REDAN), the Nigeria Building Materials Manufacturers Association (BUMPAN) and the main mortgage institution (PMI) are the three major private sector organization set up under the policy instrument. The establishment was established primarily to work with ministries, departments and government agencies (MDAs) in the provision of public housing. However, careful study of PPP institutional framework in housing in Nigeria can be seen that there is an active involvement of federal and state government bodies (eg Ministries, ICRCs, Federal Housing Authorities, National Housing Companies); private housing developer (developer of commercial real estate); financiers (e.g., commercial banks, Nigeria Federal Mortgage Bank, major mortgage institution; physical development control unit) in the implementation of PPP housing projects. sadly, unlike other countries like Malaysia, Australia and Canada, where local government authorities, housing co-operatives and other non-governmental organizations (NGOs), community-based organizations (CBOs) represent the interests of low-income people to play an active role, had seen the involvement of this organization category in PPP housing projects in Nigeria (Ibem and Alagbe, 2015). Furthermore, despite the fact that BUMPAN is special established to become an active participant in the PPP housing project, its members are also not actively involved as partners in PPP housing projects in Nigeria. As a result, the government's intention to reduce the cost of building materials in the PPP housing project through BUMPAN's involvement has yet to be achieved. This means that PPPs in housing in Nigeria are largely a joint effort between government agencies, REDAN members and financial institutions.

Consequently, the agreement among authors is that PPPs in housing do not provide any significant contribution to solving the challenges of urban housing in Nigeria, especially among low-income households. This development has been linked to several factors. This includes a lack of uniform National Policy on PPP in housing in Nigeria, relying more on a joint venture model that encourages the government to hold equity holders and share profits from PPP housing projects; high interest rates on loans used to finance PPP housing projects and high cost building materials and construction equipment. Others are the lack of adequate incentives for private sector partners, the use of high standard buildings and non-involvement of local government authorities and private sector organizations not for profit in PPP housing projects (Ibem, 2011a, Ukoje and Kanu, 2014). These background explain why PPP's experience in the Nigerian housing sector is dominated by housing for high-income and middle-income earners. This experience varies to other developing country like Malaysia (Abdul-Aziz et al., 2011), the Philippines (UN-HABITAT, 2006b) and Brazil (Fruet, 2005), that made is contrary to experience in other developing countries such as which have made significant advancement in their housing low - income population through PPP choice.

Based on Malaysia, UK, Canada, India and Australia system of PPP for affordable housing to solve the problem of housing in their country, this study tends to develop a framework that uses the success factors of Malaysia, UK, Canada, India and Australia to determine, assess for completion and suggesting a solution to the problem of Nigerian housing i.e. the Abuja capital of Nigeria where there is rapid urban migration and rising population leading to high cost of living, high rental costs, and high housing costs (Morka, 2014). Therefore, the knowledge gap is an understanding of the situation that the investigation intends to achieve

\section{B. Housing In Abuja}

According to Isma'il et al. 2014 Abuja the Capital Federal Territory of Nigeria comprising most government headquarters and government parastatals, a number of private firms, foreign organizations and investors, offices and companies. It is an area of great development, with the majority of offices, headquarters and firms located in the federal capital. Due to the level of development, the high number of municipalities by people not only moved from rural areas, but also by people moving from other parts of the states to Abuja to find a better job. As the metropolitan economy continues to improve, the public gets and continues to become richer.

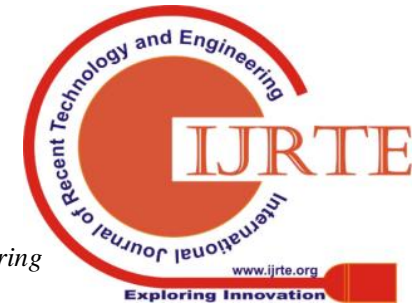


Connecting with the rush of people from various parts of the country, housing and land are seen by rich individuals as consecutive materials and therefore bought and built in the most central city. As identified by Logan and Molotch (1976), land entrepreneurs, including: Landlords, Entrepreneurs Developers, Transport and Utility Companies, Banks and Companies, and others, consider the home as a place of residence, but also as a product in the property market, which can be bought and exchanged, thereby providing exchange and use value for producers (entrepreneurs) and consumers (consumers), and therefore try, through collective action and in most cases in federation with other operators, to create conditions that will increase the future use of land in an area. Therefore, Abuja is now a city with buildings, scenarios, offices, organizations, parks, open spaces, and so forth, but also the city whose housing is very expensive even for people working in this city, except those in high class and some individuals in upper middle class society. There are several types of housing in the city, consisting of luxury homes, duplexes, bungalows and apartment blocks but all are very costly. Due to the continued influx of people to the city, the Government and some private investors have built and are still building plantations and housing developments in FCT to accommodate the growing population. The Master Plan contains proposals for housing programs that combined with subsidies to the housing sector, offer strategies to improve housing conditions in other urban areas of Nigeria. This program is based on the following principles:

1. Efficient layout of plots and appropriate infrastructure standards allow for increased standards when increasing economic capacity

2. A wide range of housing options for all income groups, from separate homes, flats, to a large number of traditional families, or home-dwelling accommodation and accommodation services

Increasing dependence on local building materials, reducing the finishing level and careful management controls to ensure that construction costs are reduced and maintained at the lowest levels

3. Site and service approach, use of self-service and self-help services to reduce costs.

Centre on Housing Rights and Evictions \& Social and Economic Rights Action Center (COHRE \& SERAC, 2008).

Today, the development of housing in Abuja has completely changed the direction of the proposed master plan proposals for housing programs that offer strategies to improve housing conditions in urban areas in Nigeria. The category of housing options in the city does not support all income groups. Although there are different home designs, which have been developed by individuals and private investors who have acquired land at very high levels of government and hence the cost of rent for these buildings is on the high side, coupled with the cost of construction and finishing population. Sometimes there is increased reliance on local building materials and the use of self-help and self-service services / modes. Currently, in the Abuja central area, the construction of many buildings and houses is done by various foreign and foreign construction companies, for example, Julius Berger, and with the use of foreign building materials, which are becoming more expensive and inexpensive housing by the low-income group and low. Hence, and the high population of other parts of the country seeking better sources of income, the government has participated in several large housing projects to accommodate the growing federal population.

\section{Affordable Housing Units Constructed In Nigeria}

The main component of the successful housing delivery program is the ability of the housing unit to target consumers. Housing is reasonable only when it does not cost more than $30 \%$ of the household income incurred (Andrew, 1998). Therefore, affordability of housing is a function of housing and household income. Therefore, this section attempts to determine the affordability of housing units built in the study area by linking household income to home prices. The question asked about housing prices is: what is the selling price of the housing unit? There was a voice response among the representatives of major actors (government agencies and the private sector), that the houses were sold at a higher price than originally agreed. The estate manager representing Terraquest Development Company Limited (ESM) said: "... house units will be built at N3.4 million for 2 bedrooms and N4.95 million for 3 bedrooms but because the government cannot provide funds for private sector infrastructure had to borrow a separate fund to finance the infrastructure, as a result, prices rose from N3.4 million to N4.2 million (2 semi semi-detached houses) and N4.95 million to N5.9 million ( 3 twin bedrooms) to accommodate the spent on providing infrastructure ". In a similar vein, ADH, said:

"The State Government cannot provide such a pre-agreed infrastructure; private companies do so. The government cannot pay the amount spent;

companies are advised to factor infrastructure costs into housing costs which then raise prices from N3.4 million to N4.2 million (2 semi-semi semi-detached houses) and N4.95 million to N5.9 million for 3 bedrooms. "Concluded from the fact that after completion of housing units, prices rose by about $23.5 \%$ and $19 \%$ for 2 semi-detached and 3 separate bedrooms. In addition, the government lost control of the project due to its inability to carry out its responsibilities as contained in the contractual arrangement, therefore, the initial arrangement that the payee will pay $10 \%$ and $20 \%$ of the advance payment (for 2 semi semi-detached and 3 bedrooms respectively) while FMBN will pay the balance to be repaid from the household's salary through the installment deduction cannot be held (ADH \& MGO). The target group is unable to pay openly because of a low salary structure; As a result, u nit-housing units are still vacant for some time and some homes have been demolished. As a result, the State Government advises private developers to search for buyers and dispose of housing units. Hence, private companies have

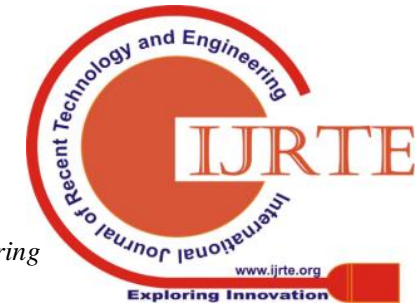


devised four ways to dispose of housing units that are open to the public. These include: 1) payment of $10 \%$ and $20 \%$ of the total cost of housing as a deposit for 23 bedroom bedrooms; 2) Rent (between N60,000 - N70,000 per annum for 2 semi semi-detached rooms and N80,000 - N100,000 per annum for 3 separate bedrooms); and 3) open sales for those who can afford it. The 2 bedroom semi-detached housing cost is N4.2 million which will be paid within 30 years which amounts to N140,000 a year; 30\% of the annual income of beneficiaries earning the N420, 000 will amount to N126, 000 which is much lower than the amount required as an annual repayment for housing. During the interview, representatives of the beneficiaries have agreed unanimously, that the prices of housing units cannot be estimated as the level of income of civil servants in the study area. Thus, this indicates that housing units built under this rule fail in the ability test. Ibem and Aduwo (2012) have reported in a similar study conducted in Ogun State, Nigeria, that the cost of housing units built through PPP is much higher than those constructed through non-PPP arrangements. In addition to the cost of home units, beneficiaries are often required to provide sureties and meet other conditions to qualify for mortgage loans which are always difficult for them to meet. One of the reasons for adopting PPPs for the provision of housing that is contrary to the direct approach is to make housing more affordable to the target group. However, studies show that the housing units provided are unavailable to most low-income people.

\section{Critical Success Factors Of Public-Private Partnership Projects}

Several researchers have investigated and developed different lists of CSFs for different PPP projects. For instance, Tam (1999) identified factors influencing the performance of BOT infrastructure development in Asia. Akintoye et al. (2003) identified success factors that contribute to the achievement of the best value in PFI projects in the UK. On the other hand, Qiao et al. (2001) identified CSFs for Build-Own-Transfer (BOT) projects in China. Jefferies et al. (2002) identified CSFs from the reflection of an Australian sports stadium project; Jamali (2004a) identified CSFs for PPP implementation in the telecommunications sector of Lebanon.

Looking at the factors contributing to PPP projects, Kwak et al. (2009) identified four CSFs from the extensive review of research studies from different administrative jurisdictions. Helmy (2011) identifies critical success factors for PPP projects in Kuwait. From an extensive review of literature and interview with experts, Zhang et al. (2001) also identified factors leading to the success of power projects. El-Sawalhi and Mansour (2014) also explored the critical success factors for PPP projects in Palestine. Gives a summary of critical success factors identified in the reviewed literature.

Given the complementarity among the lists of factors developed in the normative literature, many authors attempted to categorize CSFs into broad categories of principal success factors each with a list of success sub-factors. The categorization is to show the relationship between inter-related variables (Kleinbaum et al. 1998; Norusis 2008). For instance, Hardcastle et al. (2005) conducted a survey of managers and directors of organizations in the UK that were involved in PPP projects to investigate key success factors for public-private partnerships. The authors found that, using factor analysis method, the critical success factors can be grouped into five clusters. Other authors have also developed a similar categorization of CSFs although with some modification. For instance, Li et al. (2005) identified five groups of CSFs for PPP/PFI projects in UK construction industry, Zhang (2005) classified CSFs for PPP infrastructure development in general into five groups. Kwak et al. (2009) also identified four CSFs from the extensive literature review of research studies on PPP. In a related study, Chan et al. (2010) identified CSFs for PPP infrastructure projects in China which they grouped into seven categories of principal success factors See Tab. 2.2.

However, this study tend to use the concept of this success factors to see his significant in contribution to Nigerian PPP for affordable housing.

Table: 2.2 Identification of success factors of PPP projects

\begin{tabular}{|c|c|c|}
\hline $\begin{array}{l}\text { Success } \\
\text { Factors }\end{array}$ & Meaning & Authors \\
\hline $\begin{array}{l}\text { Favourable } \\
\text { legal } \\
\text { framework }\end{array}$ & $\begin{array}{l}\text { a) Comprehensiveness } \\
\text { of rights } \\
\text { b) Right to develop } \\
\text { c) Right to determine }\end{array}$ & 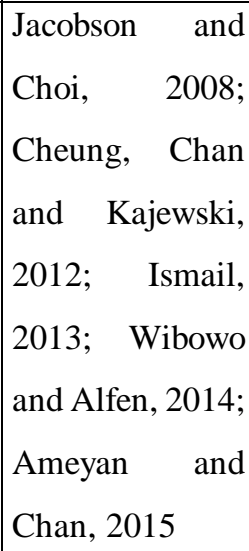 \\
\hline $\begin{array}{l}\text { Commitment/ } \\
\text { responsibility } \\
\text { of } \\
\text { public/private } \\
\text { sectors }\end{array}$ & $\begin{array}{l}\text { a) Transparency in } \\
\text { operation } \\
\text { b) Trained staff }\end{array}$ & $\begin{array}{lr}\text { Li et al., } & 2005 ; \\
\text { Jacobson } & \text { and } \\
\text { Choi, } & 2008 ; \\
\text { Ismail, } & 2013 ; \\
\text { Ameyan } & \text { and } \\
\text { Chan, 2015 }\end{array}$ \\
\hline $\begin{array}{l}\text { Project } \\
\text { Technical } \\
\text { Feasibility }\end{array}$ & $\begin{array}{l}\text { In PPP procurement } \\
\text { contracts, the } \\
\text { feasibility study should } \\
\text { review the technical } \\
\text { requirements of the } \\
\text { project and ensure any } \\
\text { engineering } \\
\text { uncertainties are } \\
\text { resolved. }\end{array}$ & $\begin{array}{lr}\text { Tiong } & \text { (1996); } \\
\text { Zantke } & \text { and } \\
\text { Mangels } & \text { (1999); }\end{array}$ \\
\hline $\begin{array}{l}\text { Technology } \\
\text { transfer }\end{array}$ & $\begin{array}{l}\text { Technology transfer is } \\
\text { the transfer of } \\
\text { knowledge and } \\
\text { experience (Chung, } \\
\text { 2001) that allows } \\
\text { company to provide }\end{array}$ & $\begin{array}{l}\text { Chou \& } \\
\text { Pramudawardha } \\
\text { ni (2015) } \\
\text { and Engin }\end{array}$ \\
\hline
\end{tabular}




\begin{tabular}{|c|c|c|}
\hline & $\begin{array}{l}\text { products or services } \\
\text { (Baranson, 1970). }\end{array}$ & \\
\hline $\begin{array}{l}\text { Good } \\
\text { governance }\end{array}$ & $\begin{array}{l}\text { It is the act of } \\
\text { steering the policies } \\
\text { and affairs of a } \\
\text { nation, an } \\
\text { organisation or } \\
\text { project (Robinson et } \\
\text { al., 2010). It relates } \\
\text { to the quality and } \\
\text { effectiveness of } \\
\text { government } \\
\text { institutions for } \\
\text { transforming policy } \\
\text { into successful } \\
\text { implementation }\end{array}$ & Ismail, 2013 \\
\hline $\begin{array}{l}\text { Competitive } \\
\text { procurement } \\
\text { process }\end{array}$ & $\begin{array}{l}\text { Competition is very } \\
\text { important when private } \\
\text { sector enterprises are } \\
\text { struggling } \\
\text { monopolise to } \\
\text { provision of public } \\
\text { infrastructure and } \\
\text { services through a } \\
\text { long-term } \\
\text { public-private } \\
\text { partnership } \\
\text { World Bank 1997). }\end{array}$ & $\begin{array}{l}\text { Gentry and } \\
\text { Fernandez } \\
\text { (1997); Kopp } \\
\text { (1997); Arthur } \\
\text { Andersen and } \\
\text { Enterprise LSE } \\
\text { (2000); Jefferies } \\
\text { et al. (2002) }\end{array}$ \\
\hline $\begin{array}{l}\text { Transparency } \\
\text { procurement } \\
\text { process }\end{array}$ & $\begin{array}{l}\text { This involves the use } \\
\text { market mechanisms for } \\
\text { the delivery of public } \\
\text { infrastructure and } \\
\text { service (Greve \& } \\
\text { Hodge, 2011). }\end{array}$ & $\begin{array}{ll}\text { Gentry } & \text { and } \\
\text { Fernandez } & \\
(1997) ; \quad \text { Kopp } \\
(1997)\end{array}$ \\
\hline $\begin{array}{l}\text { Financial } \\
\text { capability }\end{array}$ & $\begin{array}{l}\text { The public partner } \\
\text { should exercise due } \\
\text { diligence to review the } \\
\text { financial viability and } \\
\text { confirm the availability } \\
\text { of the expected } \\
\text { resources for a project. }\end{array}$ & $\begin{array}{l}\text { Jefferies (2002), } \\
\text { Zhang (2005) }\end{array}$ \\
\hline $\begin{array}{l}\text { Available } \\
\text { financial } \\
\text { market }\end{array}$ & $\begin{array}{l}\text { Availability of mature } \\
\text { financial market with a } \\
\text { diversified range of } \\
\text { financial services will } \\
\text { lower financing costs } \\
\text { thereby attracting } \\
\text { private investors to } \\
\text { PPP projects (Cheung, } \\
\text { et al. 2012). }\end{array}$ & $\begin{array}{l}\text { Li et al., 2005; } \\
\text { Cheung, Chan } \\
\text { and Kajewski, } \\
\text { 2012; Ismail, } \\
\text { 2013; Ameyan } \\
\text { and Chan, 2015 }\end{array}$ \\
\hline $\begin{array}{l}\text { Stable } \\
\text { macro-econo } \\
\text { mic } \\
\text { conditions }\end{array}$ & $\begin{array}{l}\text { The macroeconomic } \\
\text { parameters that affect } \\
\text { the economy of a } \\
\text { nation include interest } \\
\text { rate, exchange rate, } \\
\text { inflation, and cost of } \\
\text { labor and materials } \\
\text { (Keong et al. 1997). }\end{array}$ & $\begin{array}{ll}\text { Jacobson } & \text { and } \\
\text { Choi, 2008 } & \end{array}$ \\
\hline Involvement & a) Campaign activities & Zhang, 2005 \\
\hline
\end{tabular}

\begin{tabular}{|c|c|c|}
\hline of civil society & $\begin{array}{l}\text { b) Co-operative } \\
\text { activities } \\
\text { c) Citizen initiated } \\
\text { contacts } \\
\text { NGOs offer a useful } \\
\text { instrument to help with } \\
\text { the monitoring of } \\
\text { procurement, } \\
\text { tariff-setting } \\
\text { implementation and } \\
\text { processes. } \\
\text { Municipalities could } \\
\text { make use of this } \\
\text { capacity to assist them } \\
\text { in ensuring the } \\
\text { ongoing public } \\
\text { scrutiny } \\
\text { partnerships } \\
\text { (Plummer, 2002:215). }\end{array}$ & \\
\hline $\begin{array}{l}\text { An efficient } \\
\text { approval } \\
\text { process }\end{array}$ & $\begin{array}{l}\text { The public agency } \\
\text { provides policy } \\
\text { framework and } \\
\text { development } \\
\text { guidelines (Adusumilli } \\
\text { 1999); and streamline } \\
\text { the approval process } \\
\text { (Griffin 2004) in PPP. }\end{array}$ & $\begin{array}{l}\text { Jefferies, } \\
\text { Gameson and } \\
\text { Rowlinson, } \\
2002\end{array}$ \\
\hline $\begin{array}{l}\text { Sound } \\
\text { economic } \\
\text { policy }\end{array}$ & $\begin{array}{l}\text { a) Real Gross Domestic } \\
\text { Product (GDP) } \\
\text { b) The Unemployment } \\
\text { Rate } \\
\text { c) The Stock Market } \\
\text { d) The Interest Rate }\end{array}$ & $\begin{array}{l}\text { Cheung, } \\
\text { Chan and } \\
\text { Kajewski, } \\
\text { 2012; Ismail, } \\
2013\end{array}$ \\
\hline $\begin{array}{l}\text { Stable } \\
\text { Political } \\
\text { Environment }\end{array}$ & $\begin{array}{l}\text { The instability of } \\
\text { political situation } \\
\text { particularly in } \\
\text { developing countries of } \\
\text { the world endanger } \\
\text { more frequent changes } \\
\text { in government policies } \\
\text { which affect the } \\
\text { success of PPP (Wong } \\
\text { 2007). This stability } \\
\text { relies on host } \\
\text { government. }\end{array}$ & $\begin{array}{l}\text { Cheung, Chan } \\
\text { and Kajewski, } \\
2012\end{array}$ \\
\hline $\begin{array}{l}\text { Strong } \\
\text { political } \\
\text { support }\end{array}$ & $\begin{array}{l}\text { Successful partnership } \\
\text { requires strong } \\
\text { political leadership } \\
\text { (NCPPP). Cultural } \\
\text { patterns has heavily } \\
\text { influence the } \\
\text { acceptance of tolling by } \\
\text { the public. In many } \\
\text { countries free access to } \\
\text { all public roads } \\
\text { constitutes a traditionat } \\
\text { element of freedom, } \\
\text { and as such, tolling }\end{array}$ & $\begin{array}{l}\text { Wibowo and } \\
\text { Alfen, 2014; } \\
\text { Ameyan and } \\
\text { Chan, 2015 }\end{array}$ \\
\hline
\end{tabular}




\begin{tabular}{|c|c|c|}
\hline & $\begin{array}{l}\text { may be considered as } \\
\text { an unacceptable } \\
\text { measure. }\end{array}$ & \\
\hline $\begin{array}{l}\text { Government } \\
\text { guarantee }\end{array}$ & $\begin{array}{l}\text { the public sector } \\
\text { agency is required to } \\
\text { provide guarantee and } \\
\text { exercise control } \\
\text { especially where } \\
\text { accountability is } \\
\text { required; or where } \\
\text { societal norms need to } \\
\text { be protected } \\
\text { (Spackman 2002). } \\
\text { Atmo \& Duffield } \\
\text { (2014. }\end{array}$ & $\begin{array}{l}\text { Hemming } \\
(2006 a), \text { Jamali } \\
(2004 b),\end{array}$ \\
\hline $\begin{array}{l}\text { Strong } \\
\text { Government } \\
\text { support }\end{array}$ & $\begin{array}{l}\text { Strong government } \\
\text { support by providing } \\
\text { additional source of } \\
\text { financing the project } \\
\text { and other means such } \\
\text { as: } \\
\text { Faster program } \\
\text { approvals, lower land } \\
\text { premiums, } \\
\text { infrastructure cost } \\
\text { subsidies, relaxation of } \\
\text { housing standards and } \\
\text { concessions for } \\
\text { financial contributions } \\
\text { to utilities, and tax } \\
\text { breaks to encourage } \\
\text { private sector } \\
\text { participation in } \\
\text { low-income housing. }\end{array}$ & Ibem, 2010 \\
\hline $\begin{array}{l}\text { Consistent } \\
\text { monitoring }\end{array}$ & $\begin{array}{l}\text { As a continuous } \\
\text { monitoring of control } \\
\text { mechanisms, public } \\
\text { agencies monitor the } \\
\text { performance of their } \\
\text { private partners to } \\
\text { ensure they do not } \\
\text { deviate from the } \\
\text { agreement on agreed } \\
\text { outputs and behaviors. }\end{array}$ & $\begin{array}{l}\text { Abdul- Aziz and } \\
\text { Kassim (2011) }\end{array}$ \\
\hline $\begin{array}{l}\text { True } \\
\text { partnership }\end{array}$ & $\begin{array}{l}\text { Trust among the } \\
\text { partners }\end{array}$ & $\begin{array}{l}\text { Cartlidge, } \\
\text { 2006; }\end{array}$ \\
\hline $\begin{array}{l}\text { Supportive } \\
\text { community }\end{array}$ & $\begin{array}{l}\text { The community } \\
\text { supports the } \\
\text { development of PPP in }\end{array}$ & $\begin{array}{l}\text { Cheung, Chan } \\
\text { and Kajewski, } \\
2012\end{array}$ \\
\hline
\end{tabular}

\begin{tabular}{|c|c|}
\hline & $\begin{array}{l}\text { specific regions. } \\
\text { Strong and capable } \\
\text { third-party } \\
\text { organization } \\
\text { responsible for } \\
\text { community } \\
\text { mobilization and } \\
\text { mediation functions. }\end{array}$ \\
\hline
\end{tabular}

\section{METHODOLOGY}

This study is using exploratory sequential mixed methods, the purpose of the design of exploratory sequential mixed design methods involves the first qualitative data collection procedure to explore the phenomenon, and then collect quantitative data to clarify the relationships inherent in qualitative data

The study used a focus group discussion with PPP experts and identified relevant success factors for the delivery of affordable PPP housing in Nigeria as determined from the literature. The professional background of the group interviews has been determined by their understanding of the PPP project. A pilot survey is under way to examine the effectiveness of the research instrument using Cronbach Alpha and Kaiser-Meyer-Olkin statistical methods. The instrument was considered reliable and effective when preparing the questionnaire.

As described by Kumar (2005), the questionnaire project should be produced through a literature review and validated through focus group interviews and tested before being used for comprehensive data collection. The questionnaire was distributed to stakeholders of public and private developers involved in PPP housing supply in Abuja, Nigeria. A total of 350 questionnaires was randomly assigned to the target of respondents (Stakeholders from both public and private sector officials) that participated in the PPP housing and real estate developers) at FCT out of which 254 questionnaire were return. Data from questionnaire surveys were analyzed using the Statistical Package for Social Science (SPSS) software for factor analysis and smart PLS is used to analysis the data.

\section{RESULTS AND FINDINGS}




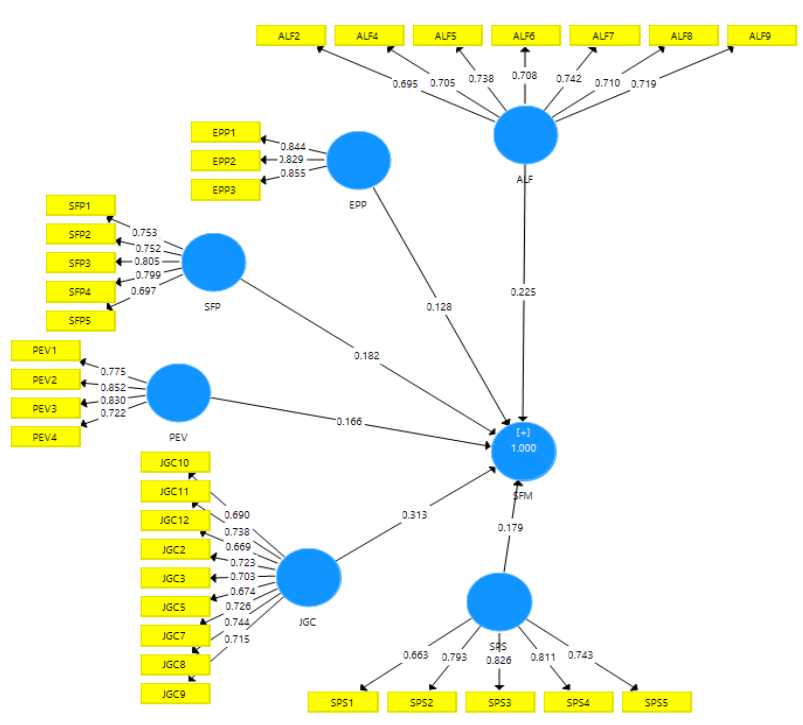

A. Table 5.5 Composite Reliability and Convergent Validity of Public Private Partnership problems Model

\begin{tabular}{|c|c|c|c|c|c|c|}
\hline $\begin{array}{l}\text { 1st } \\
\text { order } \\
\text { Const } \\
\text { ruct }\end{array}$ & $\begin{array}{l}\text { 2nd } \\
\text { order } \\
\text { Constr } \\
\text { uct }\end{array}$ & Items & \begin{tabular}{|l} 
Meas \\
urem \\
ent \\
Mode \\
I \\
Type
\end{tabular} & $\begin{array}{l}\text { Loadin } \\
\mathrm{g}\end{array}$ & CR & AVE \\
\hline 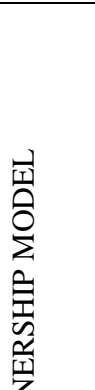 & $\begin{array}{l}\text { Adequat } \\
\text { e Legal } \\
\text { Framew } \\
\text { ork }\end{array}$ & $\begin{array}{l}\text { ALF2 } \\
\text { ALF4 } \\
\text { ALF5 } \\
\text { ALF6 } \\
\text { ALF7 } \\
\text { ALF8 } \\
\text { ALF9 }\end{array}$ & $\begin{array}{l}\text { Reflec } \\
\text { tive }\end{array}$ & $\begin{array}{l}0.695 \\
0.705 \\
0.738 \\
0.708 \\
0.742 \\
0.710 \\
0.719\end{array}$ & 0.881 & 0.514 \\
\hline 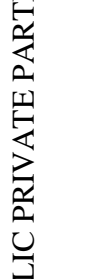 & $\begin{array}{l}\text { Effectiv } \\
\mathrm{e} \\
\text { procure } \\
\text { ment } \\
\text { process }\end{array}$ & $\begin{array}{l}\text { EPP1 } \\
\text { EPP2 } \\
\text { EPP3 }\end{array}$ & $\begin{array}{l}\text { Reflec } \\
\text { tive }\end{array}$ & $\begin{array}{l}0.844 \\
0.829 \\
0.855\end{array}$ & 0.880 & 0.710 \\
\hline 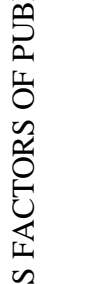 & $\begin{array}{l}\text { Sound } \\
\text { Financi } \\
\text { al } \\
\text { Package }\end{array}$ & $\begin{array}{l}\text { SFP1 } \\
\text { SFP2 } \\
\text { SFP3 } \\
\text { SFP4 } \\
\text { SFP5 }\end{array}$ & $\begin{array}{l}\text { Reflec } \\
\text { tive }\end{array}$ & $\begin{array}{l}0.753 \\
0.752 \\
0.805 \\
0.799 \\
0.697\end{array}$ & 0.901 & 0.503 \\
\hline 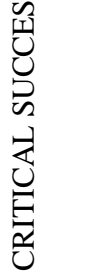 & $\begin{array}{l}\text { Project } \\
\text { Econom } \\
\text { ic } \\
\text { Viabilit } \\
\text { y }\end{array}$ & $\begin{array}{l}\text { PEV1 } \\
\text { PEV2 } \\
\text { PEV3 } \\
\text { PEV4 }\end{array}$ & $\begin{array}{l}\text { Reflec } \\
\text { tive }\end{array}$ & $\begin{array}{l}0.775 \\
0.852 \\
0.830 \\
0.722\end{array}$ & 0.874 & 0.634 \\
\hline
\end{tabular}

\begin{tabular}{|l|l|l|l|l|l|l|}
\hline & Judicial & JGC10 & Reflec & 0.690 & 0.874 & 0.581 \\
Govern & JGC11 & tive & 0.738 & & \\
ment & JGC12 & & 0.660 & & \\
control & JGC2 & & 0.723 & & \\
& JGC3 & & 0.703 & & \\
& JGC5 & & 0.674 & & \\
& JGC7 & & 0.726 & & \\
& JGC8 & & 0.744 & & \\
& Strong & SPS1 & Reflec & 0.663 & 0.878 & 0.592 \\
Private & SPS2 & tive & 0.793 & & \\
sector & SPS3 & & 0.826 & & \\
& SPS4 & & 0.800 & & \\
& SPS5 & & 0.743 & & \\
\hline
\end{tabular}

Table 5.6 Convergent validity

\begin{tabular}{|lll|} 
& \multicolumn{1}{c}{ Composite Reliability } & Average \\
& $(\mathrm{CR})$ & Extracted (AVE) \\
ALF & 0.881 & 0.514 \\
EPP_ & 0.880 & 0.710 \\
JGC & 0.901 & 0.503 \\
PEV & 0.874 & 0.634 \\
SFP & 0.874 & 0.581 \\
SPS & 0.878 & 0.592 \\
\hline
\end{tabular}

Fig 5.5 shows the critical success factors of public private partnership having a second order

Construct, Tables 5.5 and Table 5.6 Represents composite reliability, convergence validity and discriminant validity. Reflective measurement model of the appropriate legal framework, effective procurement process, sound financial package, project economic viability, judicial government control, \& strong private sector when analyzing composite reliability adequate legal framework had nine indicators, effective procurement process had three indicators, sound financial package also had five indicators, project economic viability has four indicators, judicial government control has thirteen indicators and strong private sector has five indicators.

with all the indicators of the constructs included, the result indicate that reliability values fell below the accepted minimum value from two construct, adequate legal framework and judicial government control. therefore, two items were remove from adequate legal framework that include (ALF1 and ALF3), after removing this items the composite reliability values of Adequate legal framework has now increase to a strong acceptable value of $(0.881)$. While in Judicial government control four items were remove that include ( $\mathrm{JGC} 1$, JGC4, JGC,6 and JGC13), the

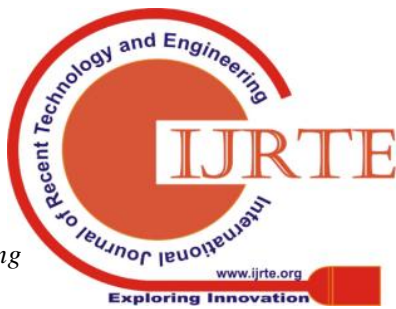




\section{Critical Success Factors of Public Private Partnership for Affordable Housing in Nigeria}

composite reliability value of Judicial government control increase to a strong accepted value of (0.874). However, after removing the items from this two construct, the adequate legal framework now has the total of seven (7) items out of the initial nine (9) items while the judicial government control that originally have thirteen items is now having nine items after removing four items for the construct to be accepted. Meanwhile, other construct has accepted value without removing any of its item, this are;

Effective procurement process has a composite reliability value of (0.880), Sound Financial Package also has a strong composite reliability value of (0.901), Project Economic Viability also has a strong composite reliability value of (0.874) and Strong Private sector has composite reliability value of (0.878). Therefore, the composite reliability value for all the construct under the critical success factors shows that all the construct have a strong acceptable value that is higher than the minimum acceptable value of 0.6 .

The reflective measured model as shows in table 5.5 after establishing the composite reliability value, the AVE were shown as follows; Adequate Legal Framework (0.514), Effective procurement process (0.710), Sound Financial Package (0.503), Project Economic Viability (0.634), Judicial Government control(0.581), and Strong Private sector $(0.592)$, this indicate that convergent validity has been accepted (Civelek,2018; Hair et al, 2014).

Table 5.6 shows discriminant validity values for the reflective constructs with all constructs HTMT value below 0.90. Therefore, discriminant validity has been accepted. However, the composite reliability, convergent validity and the discriminant validity test show that the success factors of public private partnership has a significant relationship with affordable housing in Abuja, this show that without the success factors public private partnership affordable housing cannot be provided in Abuja Nigeria.

\section{RECOMMENDATION AND CONCLUSION}

The main reason PPP in housing is to provide adequate and affordable housing for all income groups. As a research findings, PPPs Is facing a tremendous problems of housing provision in the study area, this include the acquisition and access to land, poor implementation of housing policies, adequate housing finance, difficulty of accessibility to mortgage facilities and land titles, Massive rural urban migration and cost recovery among others. Just like the previous public housing delivery strategy, this approach is skewed towards providing housing for high- and middle-income earners in Abuja and other part of Nigerian. However, the provision of affordable housing has not yet been reached in the study area. The point that there is no consensus on the State Policy on PPP in housing in Nigeria is anxiety. Since PPP for affordable housing in Abuja Nigeria is unclear. Hence, it shows that PPP practices for affordable housing are then regarded as governance controls as the main component of affordable housing. It is therefore recommended that a good policy framework for the implementation of other variants of PPPs in meeting the affordable housing in Nigeria should be consider on the constituent parameter of affordable housing. First of all, it will wipe out all the underlying constraints that cannot define local government authorities and grassroots organizations in PPP for affordable housing, and then provide the needs of different socioeconomic groups in the country's sub sector of housing in Nigeria. Land allocation and government rights documents at premium cost add to the cost of housing provided by PPP.

To this end, the government may consider providing free land for affordable housing to ensure the ability and profitability of commercial private sector partners. We can also follow Malaysia's example of providing affordable housing for all income groups, so that cheaper and local materials can be used instead of expensive and imported in building affordable housing units. Likewise, self-help options and government-assisted housing options should be included in the PPP housing scheme to provide more affordable housing for all income group at a reasonable amount.

Public private partnership Contribution (PPP) although the current mortgage arrangement in the National Housing Fund (NHF) is commendable, there is still much to be done to facilitate easy access by Nigerians to mortgage facilities. This refers to the provision of fast facilities to qualified applicants. In addition, funds from the contribution pension scheme can be injected into affordable housing under PPP arrangements to enable low-income group and people interested in gaining access to affordable housing through their pension contributions. There is also an urgent need to empower the low income people financially by providing them with more job opportunities. This can be achieved through a multi-sectorial approach to agriculture, manufacturing, education, better acquisition of skills and wages and should be targeted towards providing this Nigerian economic group the necessary economic power to acquire a decent housing unit. Finally, since the PPP is a relatively new approach to public housing in Nigeria, some initial challenges are expected. Therefore, its implementation should incorporate the recommendations made in this paper to ensure better return on affordable housing for all income groups.

\section{ACKNOWLEDGEMENTS}

The author is grateful to Almighty Allah for giving me ability to write this paper. A special honour to my supervisor Ass. Prof Dr. Ibrahim Atan Bin Sipan of Department of Property Management, Faculty of Built Environment and surveying, Universiti Teknologi Malaysia, 81310 Skudai, Johor, Malaysia for given me his time, full support in sharing his knowledge to make me understand the process of research. I want to thank organization for sending me to Malaysia to acquire new knowledge and lastly, I want to thank the UTM for admitting me as a research student of this greet institution of learning, $i$

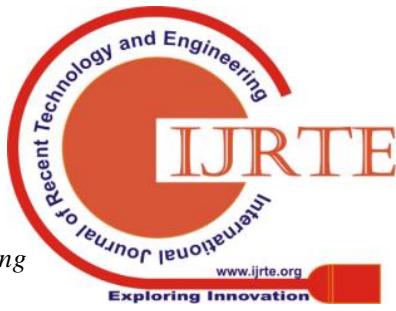


say thank you UTM.

\section{REFERENCE}

[1] Abdul-Aziz. A-R. \&Kassim, PSJ, 2011. Objectives, success and failure factors of housing public e private

[2] partnerships in Malaysia. International, 35(1), pp150-157.

[3] Abdul-Aziz. A-R., 2012. Control mechanisms exercised in Malaysian housing public-private partnerships.

[4] Construction management and economics, 30(1), pp.37-55.

[5] Abdul-Aziz. A., 2010. Housing private public partnerships: perspectives from the government Agencies.

[6] In NAPREC conference. Pp. 1-24.

[7] Abdullahi, B.C. \& Abd-Aziz, N.A., 2011. The roles of private sector participation in achieving anticipate

[8] outcomes for low-come group: A comparative analysis of housing sector between Malaysia and

[9] Nigeria. African journal of business management, 5(16), pp.6859-6890.

[10] Ade-Kunle Ifesanya, 2012. The Role of Government agencies in urban housing delivery insufficient

[11] political will and ineffective housing administration in lagos metropolis - case study of Ajegunle, Lagos. A thesis submitted for the requirement of the award of $\mathrm{PhD}$ in Urban Studies at the Institute for European Urban Studies, Faculty of

Architecture, Bauhaus University, Weimar, Germany.

Ademiluyi, A.I. \& Raji, B.A. (2008) Public and private developers as agents in urban housing

[12] delivery in sub-Saharan Africa: the situation in Lagos State. Humanity \& Social Sciences Journal, 3(2), pp.143-150. African Ministerial Conference on Housing and Urban Development (AMCHUD) (2005) Communiqu'e

[13] on 'financing housing and urban development: with special reference to Africa' issued at the end

[14] of the conference 31 January-4 February, Abuja, Nigeria.

Agbola, T. and Jinadu, A. (1997) Forced eviction and forced relocation in Nigeria: the

[15] experience of those evicted from Maroko in 1990, Environment and Urbanization

[16] 9 (271), 270-288.

[17] Agrawal, R., 2010, successful delivery of public -private partnership for infrastructure development. Jaypee

[18] institute of information technology .neada India.

[19] Ajibola G.B \& Sanmi A. (2015). Housing Rehabilitation Strategy as Enabling Approach for Development

of Rural Housing Poverty in Nigeria. World Journal of Social Sciences and Humanities Vol. 1, No. 1, 2015, pp 11-17. doi: 10.12691/wjssh-1-1-3.

[20] Akintoye A. et al., 2003. Achieving best value in private finance initiative project procurement.

[21] Construction management and economics, 21(5), pp 461-470.

[22] Akintoye,A., 2015. Ppp: variations and country contexts. Keynote address. In environmental design and

[23] management international conference (EDMIIC2015) at obafemi Awolowo University. March

[24] 2015. IIE-Ife, Nigeria.

Ameyaw, E.E. and Chan, A.P. (2015), "Risk ranking and analysis in PPP water supply infrastructure

[25] projects: an international survey of industry experts", Facilities, Vol. 33 Nos 7/8, pp. 428453.

[26] Ameyan, E. E. and Chan, A.P.C., 2015. Implementing PPP Water Supply Projects in Ghana. African Journal of Applied Research, 1(1), pp.453-69.

[27] Aribigbola, A. 2008. Housing Policy Formulation in Developing Countries: Evidences of Programme Implementation from Akure, Ondo State Nigeria. . Journal of Human Ecology 23, 125-134.

[28] Arthur Andersen and Enterprise LSE, (2000). Value for Money Drivers in the Private Financial Initiative, the Treasury Task Force, http://www treasury-

rojectstaskforce.gov.uk/series_1/andersen/7tech_contents.html. [Accessed September 2018].

[29] Ar M.M. and Gab-Allah A.A. (2002) Problems Facing Parties Involved in Build, Operate, and Transport

[30] Projects in Egypt . JOURNAL OF MANAGEMENT IN ENGINEERING / OCTOBER 2002 /.

Association of Consultin engineering Companies, 2015. Understanding Public Private Partnerships in

[31] Canada. Report, p.36. Access on: 12 october, 2018 at http://www.acec.ca/.

Australian Housing and Research Institute (AHURI) (2004) Measuring housing affordability, AHURI
[32] Research and Policy Bulletin, (45), pp. 1-4.

[33] Awodele,O.A.ogunsemi, D.R. \& rotimi, JOB. 2008. Private participation in infrastructure $(\mathrm{ppI})$

[34] development in developing economies-the Nigerian experience. In the construction and building

[35] research conference of the royal institution of chartered surveyors. Dublin.

[36] Awotona, A. (1990). Nigerian government participation in housing: 1970-1980. Habitat International, $14 \quad$ (10), 17-40.

[37] Bana, P. M. (1991). Housing the urban poor in Nigeria. The Nigerian Institute of Architects Journal, 6(1),

[38] 22-25. Batley, R.

Brown, A., Allison, O., \& Luo, J. (2006). The suitability of Public-Private Partnership in the provision of

[39] sustainable housing in China. World Review of Entrepreneurship, Management and sustainable

[40] Development, 1(1/2), 101-124.

Carol Jacobson, Sang Ok Choi (2008), public works and public-private partnerships. International Journal of Public Sector Management Success factors:

[41] Cartlidge, 2006, Public Private Partnership in Construction. ISBN13:978-0-415-36621 2(HBK). https://www.amazon.com/Public-Private-Partnerships-Construction-Car tlidge/dp/B007YZVSZK

[42] Chan. A.P.C. et al., 2010.crical success factor for PPs in infrastructure Developments: Chinese perspective. Journal of construction. Engineering and management, 136(5), pp.484-494.

[43] Cheung, Esther, Chan, Albert, \& Kajewski, Stephen L. (2012) Factors contributing to successful public private partnership projects: comparing Hong Kong with Australia and the United Kingdom. Journal of Facilities Management, 10(1), pp. 45-58.

[44] Chou, J. S., \& Pramudawardhani, D. (2015). Cross-country comparisons of key drivers, critical success

[45] factors and risk allocation for public-private partnership projects International Journal of Project

[46] Management, $33(5)$,

$1136-1150$ https://doi.org/10.1016/j.ijproman.2014.12.003〉.

[47] Dewulf, G., mahalingam, A \& jooste, S. 2011. The transition towards a sustainable PPP regime in T. M.,

[48] tooled, Ed engineering project organization conference Colorado, p 14.

[49] El -sawalhi, N.I.,\& mansour, M.A., 2014 preparation critical success factor for public private partnership (ppp) projects in Palestine. Journal of engineering research and technology, 1(2), pp.52-57.

[50] Federal Republic of Nigeria (1991) National Housing Policy (Lagos Federal Government Press).

[51] Federal Republic of Nigeria (2009). National Policy on Public Private Partnerships. Abuja: Infrastructure Concession Regulatory Commission (ICRC).

[52] Frilet, M. (1997). Some Universal Issues in BOT Projects for Public Infrastructure, The International Construction Law Review. 14 (4). pp.499-512.

[53] Fruet, G.M. (2005) The low-income housing cooperatives in Porto Alegre, Brazil: a State/CommunityPartnership, Habitat International, (29), 300-324.

[54]

Gentry B. and Fernandez, L. (1997) Evolving Public-Private Partnerships: General Themes and Urban Water Examples Globalisation and the Environment: Perspectives from OECD and Dynamic Non-Member Economies. OECD, Paris. pp.19-25 http://www.undp.org/pppue/. [Accessed June 2018].

Ibem, E. O. 2010. An Assessment of the Role of Government Agencies in Public-Private Partnerships in Housing Delivery in Nigeria. Journal of Construction in Developing Countries, 15, 23-

[55] Ibem, E. O. (2011a). Public-Private Partnership (PPP) in housing provision in lagos megacity region, Nigeria. International Journal of Housing Policy, 11(2), 133-154. https://doi.org/10.1080/14616718.2011.573204

[56] Ibem, E. O. (2011b). The contribution of Public-Private Partnerships (PPPs) to improving accessibility of low-income earners to housing in southern Nigeria. Journal of Housing and the Built

Environment, $26(2)$, https://doi.org/10.1007/s10901-011-9213-1.

[57] Ibem, E.O; Anosike, M.N. and Azuh, D.E. (2011). Challenges in Public Housing Provision in the Post- Independence Era in Nigeria. International Journal of Human Sciences $8 \quad$ (2), 421-443.

[58] Ibem, E. O. \& Aduwo, E. B. 2012. Public-Private Partnerships (PPPs) in Urban Housing in

Nigeria: Evidence from Ogun State. International Journal O

Architecture and Urban development, 2 


\section{Critical Success Factors of Public Private Partnership for Affordable Housing in Nigeria}

Hardcasle, C. et al., 2005. Critical Success Factors for PPP/PFI Projects in the UK Construction Industry:

[59] A Factor Analysis Approach. Construction Management and Economics, 23(5), pp. 1-9.

Hair et al, 2014. Partial least squares structural equation modeling (PLS-SEM) An emerging tool in

[60] business research. European Business Review Vol. 26 No. 2, 2014 pp 106-121.

[61] Ham H.V. \& Koppenjan J. (2010). Building Public-Private Partnerships: Assessing and managing risks in

[62] port development. Public Management Review ISSN 1471-9037 print/ISSN 1471-9045 online

[63] Vol. 4 Issue 12002 593-616.

[64] Helmy. M.A.,2011 investigating the critical success factors for ppp projects in kuwau royal institute of

[65] technology, Stockholm.

[66] Hemming,R.,2006a., public- private partnership in realizing the potential for profitable investment in

[67] Africa. Tunis, Tunisia: organized by the IMF institute and the joint Africa institute, p.15.

[68] Ikekpeazu, F. (2004). New trends in low-cost housing delivery systems in Nigeria: An overview of

[69] the Public-Private Partnership approach. Housing Today-The Journal of the Association of Housing Corporation of Nigeria, 1(8), 30-36.

[70] Ismail A.G. , 2013. Public Private Partnerships: lesson from Sukuk. Islamic Research and Training Institute P.O. Box 9201, Jeddah 21413, Kingdom of Saudi Arabia.

[71] Ismail S, 2014 Critical success factors of public private partnership (PPP) implementation in Malaysia. Asia-Pacific Journal of Business Administration Vol. 5 No. 1, 2013 pp. 6-19

[72] Jacobson C. \& Choi S.o. , (2008) "Success factors: public works and public-private partnerships", International Journal of Public Sector Management, Vol. 21 Issue: 6, pp.637-657, https:// doi.org/10.1108/09513550810896514.

[73] Jamil, D., 2004b. Success and failure mechanisms of public private

[74] countries, The International Journal of Public sector Management, 18(5), pp.414-430.

[75] Jefferies, M., Gameson, R. and Rowlinson, S. (2002). Critical Success Factors of the BOOT Procurement System: Reflection from the Stadium Australia Case Study. Engineering, Construction and Architectural Management. 9 (4). pp.352-361.

[76] Jimiez, E. \& Kieve, H. (1983) Progressive development and affordability in the design of urban shelter

[77] programme, World Bank Working Paper 560, p. 83.

[78] Kanter, R. M. (1999). From Spare Change to Real Change, Harvard Business Review. Boston. 77 (2). pp.122-132

[79] Kleinbaum, D.G., Kupper, L.L. \& Muller, K.E., 1998. Applied Regression Analysis and other

[80] Multivariable Methods, Boston, Mass.: PWS-Kent Pub. Co., c1988.

[81] Klijn, E.H. \& Koppenjan, J.M. (2000) Public management and policy networks: foundation of a network

[82] Approach to governance. Public Management, 2(2), pp. 135-158

[83] Kopp, J. C. (1997). Private Capital for Public Works: Designing the Next-Generation Franchise for Public-Private Partnerships in Transportation Infrastructure. Master Thesis, Department of Civil Engineering, Northwestern University, USA http://iti.acns.nwu.edu/clear/infr/kopp/index.htm. [Accessed June 2018].

[84] Kwak, Y.H., chih Y. \& ibbs, C.W., 2009. Towards a comprehensive understanding_of public private partnerships for infrastructure development California management review, 51(2), pp. 51- 78

[85] Lagos State Government (2008) Lagos State Government PPP initiatives, PPP Brochure (Ikeja: Ministry

[86] Of Finance). Available at http://www.lagostate.gov.ng (accessed 14 May 2018).

[87] Li, B. et al., 2005a. Critical success factor for PPP/PFI projects in the UK construction industry construction

[88] 'Management and economics. 23(5), pp. 459-471.

[89] Li, B.Akintoye, A. 2008. An Overview of Public Private Partnership. In A. Akintoye, M. Beck, \& C.

[90] Hardcasle, eds. Public-Private Partnerships. Oxford, UK: Blackwell Publishing Inc., pp.1-30.

[91] Mayaki, S. S. (2003). Private sector involvement in mass housing: The way forward. Housing Today-

[92] Journal of the Association of Housing Corporations of Nigeria, 1(7), 31-34.

[93] Mba, H. C. (1992). The Dilemmas of housing programmes in Nigeria. In H. C. Mba, J. U. Ogbazi, \&

[94] K. O. Efobi (Eds.), Principles and practice of urban and regional pasrtnership (PPPs) in Developing planning in Nigeria (pp. 52-62).

[95] Awka: Mekslink Publishers Nigeria.

[96] Morka, F.C. (2007) A place to live: a case study of the Ijora-Badia community in Lagos, Nigeria. Case Study Prepared for Enhancing Urban Safety and Security Global Report on Human Settlement. Available at http://www.habitat.org/grhs/2007 (accessed 27 April 2018).

[97] Miraftab, F. (2004) Public-Private Partnerships: Trojan horse of neoliberal development? Journal of Planning Education and Research, 24(1), 89-101.

[98] Mukhija, V. (2004). The contradiction in enabling private developers of affordable housing: A cautionary

[99] case from Ahmedabad, India. Urban Studies, 41(11), 2231-2244.

[100]Mustafa Emre Civelek 2018 Essentials Of Structural Equation Modeling.

[101]National Audit Office (2001). Managing the Relationship to Secure a Successful Partnership in PFI Projects. National Audit Office, London. HC375.

[102]Norusis, M., 2008. SPSS 16.0 Advanced statistical procedures companion, prentice hall press. Available

at:http://dl.acm.org/citation.cfm?id=1628706[accessed December 6, 2018]

[103]Payne, G. (Ed.). (1999). Making common ground: Public-Private Partnerships in land for housing.

[104] London: Intermediate Technology Publications.

[105]Qiao, L., Wang, S., Tiong, R. and Chan, T. (2001). 'Framework for critical success factors of BOT

[106] projects in China'. The Journal of Structured Finance, 7: 1, 53-61.

[107] Obeng-Odoom, F. (2009). Has the habitat for humanity housing scheme achieved its goal? A Ghanaian case study. Journal of Housing and the Built Environment, 24, 67-84.

[108] Ogu, V. I., \& Ogbuozobe, J. E. (2001). Housing policy in Nigeria: Towards enablement of private housing development. Habitat International, 25(4), 473-492.

[109]Ong, H.C. \& lenard, D., 2002.can private finance be applied in the provision of housing :

[110] In FIG XXII international congress. Washington, D.C., p. 13.

[111] Ong, H. C. and Lenard, D. (2002). Partnerships between Stakeholders in the Provision of and

[112] Access to Affordable Housing in Malaysia. Paper presented at FIG XXII.

[113] International Congress held at Washington, D.C., USA, April 19-22, 2002.

[114]Onibokun, A. G. (1982) Issues in Nigerian Housing, Ibadan, NISER.

[115] Oruwari, Y. (1993). Affordability of urban housing in Nigeria. The Nigerian Institute of Architects Journal, 8(1\&2), 26-30.

[116] Owei, O. (2007) Distortions of the urban land markets in Nigerian cities and the implications for

[117] urbangrowth patterns; the case of Abuja and Port Harcourt. Pape presented at the Fourth Urban

[118]Research Symposium. Available at: http://www.Worldbank.org (accessed 22 June 2018).

[119] Oruwari, Y. (2006). Lest we forget: The poor people need housing in the urban areas in Nigeria too-A reflection of low-income housing provision. In A. I. Okewole, et al. (Eds.), The built environment: Innovation policy and sustainable development (pp. 2-9) Ota-Nigeria: Department of Architecture, Covenant University.

[120]Rondinelli, D.A (1990) Housing the urban poor in developing countries: other policy options for national

[121] Shelter strategies are examined since conventional ones are inadequate, American journal of Economics and Sociology, 49(3), pp. 257-269. Available at: http://www.jstor.org (accessed 24 February

[122] 2018)

[123] Sengupta, U., 2005. Government intervention and public -private partnerships in housing delivery in kolkata international, p.14.

[124] Shelter Afrique (2008) Mortgage financing for increased access to housing inAfrica, Symposium organized jointly by Shelter Afrique and the Ministry of Housing, republic of Togo, Lome, 10 June. Available at: http://www.shelterafrique.org (accessed 15 July 2018).

[125] Stonehouse, J. H., Hudson, A. R. and O'Keefe, M. J. (1996) Private-Public Partnerships: The Toronto Hospital Experience. Canadian Business Review. Ottawa. 23 (2). pp.17-20.

[126]Tam, C.M., 1999. Build-operate transfer model for infrastructure development in Asia: reasons for successes and failures. International journal of project management, 7 , pp.377- 382 .

[127]Tiong, R. (1996). 'CSFs in competitive tendering and negotiation model for BOT 
projects'. Journal of Construction Engineering and Management, 122: 3, 205-211.

[128]Trivedi, J \& Ajit, I., 2014. A Public private partnership model for provision of housing to urban poor, p, 19. available at: www.researchgate.net/publication/[accessed July 1.2018].

[129]UNCHS. (1992). Global strategy to the year 2000. Nairobi: UNCHS

[130]UN-HABITAT, 2005. Financing urban shelter: global report on human settlements 2005, Nairobi, Kenya.

[131]UN-HABITAT (2006a) Shelter for all: The potential of housing policy in the implementation of the habitat agenda, Nairobi: UN-HABITAT Information Services Section. Online http://www.unhabitat.org/.

[132]UN-HABITAT (2006b). Public-Private Partnerships in enabling shelter strategies. Nairobi: United.

[133]UN-HABITAT (2010). The State of African Cities 2010-Governance, Inequality, Urban Land Markets, Nairobi: United Nations Human Settlements Programme.

[134] United nations economic commission for Europe. 2008. Guide book on promoting good governance in public-private partnerships, Geneva, Switzertural United Nations.

[135] United Nations. 2014. World urbanization prospects: the 2014 revision highlights. New York: United Nations.

[136]World Bank 1993. Housing: Enabling markets to work. A World Bank policy paper. Washington DC.: The World Bank.

[137]Wibowo, A. and Alfen, H. W., 2014. Identifying macro-environmental critical success factors and key Areas for improvement to promote public-private partnerships in infrastructure. E engineering, Construction and Architectural Management, 21(4), pp.383-402. doi: http://dx.doi.org/10.1108/ECAM-08-2013-0078.

[138]Wibowo, A.\& aifen, H.W., 2015. Government-led critical success factors in ppp infrastructuredDevelopment. Built environment project and asset management, 5(1), pp. 121-134.

[139]Zhang, X., 2005b. Criteria success factors for public private partnerships infrastructure development. Journal of construction engineering management, 131(1), pp.3-14.

[140]Zhang, X.Q. \& kumaraswamy, M.M., 2001. hong kong experience in ma BOT projects. Journal Of construction engeering and maning march/ april, pp. 154-162.

[141]Zantke G. and Mangels B, (1999) "Public sector client-private sector project: transferring the state Construction administration into private hands", Engineering, Construction and Architectural Management, Vol. 6 Issue: 1, pp.78-87, https://doi.org/10.1108/eb021101.

\section{AUTHORS PROFILE}

Yahaya Ahmed from I am from Faculty of Built Environment and surveying, Department of Property Development, Universiti Teknologi Malaysia, 81310 Skudai, Johor, Malaysia. My area of interest is governance issues.

I am Ibrahim Atan Bin Sipan from Faculty of Built Environment and surveying, Department of Property Development, Universiti Teknologi Malaysia, 81310 Skudai, Johor, Malaysia. My area of interest is corporate sustainability. 